\title{
4-Quinolone-resistant Neisseria gonorrhoeae in the United Kingdom
}

\author{
W. R. GRANSDEN, CHRISTINE WARREN and I. PHILLIPS
}

Department of Microbiology, United Medical and Dental Schools of Guy's and St Thomas' Hospitals, St Thomas' Campus, London SE1 TEH

\begin{abstract}
Summary. The auxotype, serogroup and antimicrobial susceptibility of 977 clinical isolates of Neisseria gonorrhoeae obtained at St Thomas' Hospital, London, during 1989 were determined; 23 isolates from 15 patients were resistant to 4-quinolones. Twelve of the patients acquired their infection in the UK and these strains were generally sensitive to other antimicrobial agents; strains from 10 patients were of serogroup IB-6. Three patients acquired their strains outside the UK and these isolates were multi-resistant and of different serogroups.
\end{abstract}

\section{Introduction}

In-vitro investigations on the efficacy of 4-quinolone antimicrobial agents against gonococci have generally indicated excellent activity. Uncomplicated gonorrhoea has responded to treatment with ciprofloxacin in single oral doses ranging from $500 \mathrm{mg}$ to as low as 100 mg. ${ }^{1-4}$ Recently, we reported treatment failure when the minimum inhibitory concentration (MIC) of ciprofloxacin for the infecting strain was $0.06 \mathrm{mg} / \mathrm{L}$ and the sensitivities to other 4-quinolones were correspondingly reduced. ${ }^{5}$ The PHLS National Gonococcus Reference Unit subsequently reported 18 strains of Neisseria gonorrhoeae for which the MIC of ciprofloxacin was $0.05-0.25 \mathrm{mg} / \mathrm{L}$ and suggested that there had been three treatment failures. ${ }^{6}$ No data were provided on the prevalence of such strains. Only two of the infections were known to have been contracted in the UK and none of the isolates was sensitive to penicillin.

In 1989 we determined the antimicrobial susceptibility, auxotype and serogroup of all clinical isolates of $N$. gonorrhoeae obtained during the year. We investigated further those strains found to have reduced sensitivity to ciprofloxacin, to assess their prevalence and to study the possible mechanisms of resistance.

\section{Materials and methods}

All gonococci isolated in St Thomas' Hospital during 1989 were identified by a monoclonal antibody co-agglutination technique (Phadebact), performed on oxidase-positive isolates with typical colonial appearance and morphology in Gram's stain growing on gonococcal selective medium (Columbia Agar with saponin-lysed horse blood $10 \%$ and VCAT supplement (Oxoid), to give a final concentration of vancomycin $2.0 \mathrm{mg} / \mathrm{L}$, colistin $7.5 \mathrm{mg} / \mathrm{L}$, amphotericin B $1.0 \mathrm{mg} / \mathrm{L}$ and trimethoprim $3.0 \mathrm{mg} / \mathrm{L}$ ).

Twelve monoclonal antibodies (Syva USA, Palo Alto, CA) provided by Dr C. A. Ison (St Mary's Hospital, London) were used to serotype the isolates and we used the method of Ison and Easmon. ${ }^{7}$ The designation of serovars was in accordance with the nomenclature of Knapp et al. ${ }^{8}$ Auxotyping was performed by the method of Copley and Egglestone. ${ }^{9}$

A 6-mm disk containing ciprofloxacin $0 \cdot 1 \mu \mathrm{g}$ was applied to cultures on DST agar with lysed blood $5 \%$ to screen for reduced sensitivity to ciprofloxacin; we had found that zones of inhibition $<25 \mathrm{~mm}$ diameter correlated with MIC values $\geqslant 0.03 \mathrm{mg} / \mathrm{L} .{ }^{5} \mathrm{MICs}$ of penicillin, tetracycline, erythromycin, cefuroxime, chloramphenicol, spectinomycin and ciprofloxacin were determined for all isolates by an agar dilution method ${ }^{10}$ with an inoculum of $10^{4} \mathrm{cfu}$, and incubation in $\mathrm{CO}_{2} 7 \%$ in air.

Our preliminary results indicated that the majority of isolates with reduced sensitivity to ciprofloxacin (MIC $>0.008 \mathrm{mg} / \mathrm{L}$ ) were serovar IB-6. To assess the possible mechanism of resistance of these strains, MICs of nalidixic acid, acrosoxacin, ofloxacin, cefoperazone, fusidic acid, rifampicin and novobiocin were subsequently measured for (i) ciprofloxacin resistant gonococci, (ii) all serovar IB-6 isolates, and (iii) a selection of other serovars representative of the overall distribution.

\section{Results}

During 1989, 977 clinical isolates of $N$. gonorrhoeae were obtained; most were from patients attending the St Thomas' Hospital Department of Genito-!urinary medicine but some were from patients of general 
Table I. Isolates of $N$. gonorrhoeae, St. Thomas' Hospital 1989

\begin{tabular}{|c|c|c|}
\hline Period & $\begin{array}{c}\text { Number of } \\
\text { isolates of } \\
N . \text { gonorrhoeae }\end{array}$ & $\begin{array}{c}\text { Number with MIC } \\
\text { of ciprofloxacin }> \\
0.008 \mathrm{mg} / \mathrm{L} \\
\text { (number representing } \\
\text { the first isolate } \\
\text { from a patient) }\end{array}$ \\
\hline January-May & 377 & 0 \\
\hline June & 79 & $4 \quad(3)$ \\
\hline July & 89 & $2(0)$ \\
\hline August & 96 & 4 (2) \\
\hline September & 90 & 3 (3) \\
\hline October & 86 & 3 (2) \\
\hline November & 54 & 3 (2) \\
\hline December & 88 & 4 (3) \\
\hline Total & 959 & $23(15)$ \\
\hline
\end{tabular}

practitioners. Not all isolates survived to be available for every investigation. The most prevalent auxotypes among 913 isolates of $N$. gonorrhoeae available for typing were: prototrophic ( $42 \cdot 1 \%)$, arginine-requiring $(20.5 \%)$, arginine-, hypoxanthine- and uracil-requiring $(13 \cdot 7 \%)$, and proline-requiring $(7 \cdot 7 \%)$.

Serotyping of the 913 available isolates showed that the most common of the 652 IB serovar isolates were IB-3 $(25 \cdot 7 \%$ of the total), IB-2 (10.9\%), IB-6 (8.5\%), IB-1 (6.6\%), IB-16 (6\%) and IB-8 (3.1\%). Of 240 IA serovar isolates, the most common was IA-2 $(18 \cdot 1 \%$ overall) with the remaining IA serovars accounting for only $8.2 \%$ of all isolates. Twenty-one isolates reacted with both IA and IB monoclonal antibodies.
MICs of ciprofloxacin for 913 isolates were found to have a mean value of $0.002 \mathrm{mg} / \mathrm{L}$, with an MIC50 of $0.002 \mathrm{mg} / \mathrm{L}$ and an MIC90 of $0.004 \mathrm{mg} / \mathrm{L}$. Only 23 $(2.5 \%)$ isolates, from 15 patients, had MICs of ciprofloxacin $>0.008 \mathrm{mg} / \mathrm{L}$. The first of these less sensitive isolates occurred in June 1989 and from then until the end of the year such strains represented $4.0 \%$ of gonococci isolated at St Thomas' Hospital (table I). Table II lists the clinical and microbiological features of the 15 patients from whom ciprofloxacin-"resistant" strains were isolated. Twelve of the patients were male, of whom five were homosexual. Two pairs of patients were known contacts. All but three patients acquired their infection in the UK; the exceptions were two patients whose contacts were in the Philippines and one who acquired infection in the USA. The initial sensitivity data and other microbiological findings for these isolates are summarised in table III.

These patients may be considered in two groups according to where their infection was acquired-in the UK (12 patients) or abroad (3). With the exception of two patients with non-reacting serovars, all the UK patients' isolates were serovar IB- 6 whereas the other patients each had a different serovar. The IB- 6 isolates were distinguishable by auxotype into either prototrophic or arginine-requiring strains.

The isolates acquired abroad were generally more resistant than the UK strains; all the latter group were sensitive to penicillin, whereas the foreign strains had reduced penicillin sensitivity and one produced penicillinase. The foreign strains were more resistant to tetracycline, erythromycin, cefuroxime and ciproflox-

Table II. Details of patients with ciprofloxacin-resistant $N$. gonorrhoeae during 1989

\begin{tabular}{|c|c|c|c|c|c|}
\hline $\begin{array}{l}\text { Patient } \\
\text { no. (sex) }\end{array}$ & $\begin{array}{c}\text { Month of } \\
\text { presentation }\end{array}$ & $\begin{array}{c}\text { Sites } \\
\text { yielding } \\
\text { gonococci }\end{array}$ & $\begin{array}{c}\text { Country } \\
\text { where infection } \\
\text { was acquired }\end{array}$ & Treatment & Outcome \\
\hline $1(\mathrm{M})^{*}$ & June & $\mathbf{U}$ & UK & Ampicillin $2 \mathrm{~g}$ probenecid $1 \mathrm{~g}$ & Cure \\
\hline $2(\mathrm{~F})^{*}$ & June & $\begin{array}{c}\mathrm{U}, \mathrm{C} \\
\mathrm{C}\end{array}$ & $\begin{array}{l}\text { UK } \\
\ldots\end{array}$ & $\begin{array}{l}\text { Ampicillin } 3 \mathrm{~g} \text { probenecid } 1 \mathrm{~g} \\
\text { Ciprofloxacin } 250 \mathrm{mg} \times 1\end{array}$ & $\begin{array}{l}\text { Failure } \\
\text { Cure }\end{array}$ \\
\hline $3(\mathrm{M})$ & June & $\begin{array}{l}\mathbf{U}, \mathbf{T} \\
\mathrm{T} \\
\mathrm{T}\end{array}$ & $\begin{array}{c}\text { Philippines } \\
\ldots \\
\ldots\end{array}$ & $\begin{array}{l}\text { Ampicillin } 2 \mathrm{~g} \text { probenecid } 1 \mathrm{~g} \\
\text { Tetracycline } 2 \mathrm{~g} / \text { day } \\
\text { Co-trimoxazole } 2.4 \mathrm{~g} \times 3\end{array}$ & $\begin{array}{l}\text { Failure } \\
\text { Failure } \\
\text { No follow-up }\end{array}$ \\
\hline $4(\mathrm{M})$ & Aug & $\begin{array}{l}\mathrm{U} \\
\mathrm{U} \\
\mathrm{U}\end{array}$ & $\begin{array}{l}\text { UK } \\
\ldots \\
\ldots\end{array}$ & $\begin{array}{l}\text { Co-trimoxazole } 2.4 \mathrm{~g} \times 3 \\
\text { Ciprofloxacin } 250 \mathrm{mg} \times 1 \\
\text { Ciprofloxacin } 500 \mathrm{mg} 3 \text { days }\end{array}$ & $\begin{array}{l}\text { Failure } \\
\text { Failure } \\
\text { Cure }\end{array}$ \\
\hline $5(\mathrm{M})$ & Aug & $\mathbf{U}$ & UK & Ampicillin $2 \mathrm{~g}$ probenecid $1 \mathrm{~g}$ & Cure \\
\hline $6(\mathrm{~F})$ & Sept & $\mathrm{C}$ & UK & Ampicillin $2 \mathrm{~g}$ probenecid $1 \mathrm{~g}$ & Cure \\
\hline $7(\mathrm{M})$ & Sept & $\mathrm{U}$ & UK & Ampicillin $2 \mathrm{~g}$ probenecid $1 \mathrm{~g}$ & Cure \\
\hline $8(\mathrm{~F})$ & Sept & C & UK & Amoxycillin $3 \mathrm{~g}$ probenecid $1 \mathrm{~g}$ & Cure \\
\hline 9 (M) & Oct & $\mathrm{U}$ & UK & Ampicillin $2 \mathrm{~g}$ probenecid $1 \mathrm{~g}$ & Cure \\
\hline $10(\mathrm{M})$ & Oct & $\begin{array}{l}U \\
U\end{array}$ & $\begin{array}{c}\text { Philippines } \\
\ldots\end{array}$ & $\begin{array}{l}\text { Ciprofloxacin } 250 \mathrm{mg} \times 1 \\
\text { Ampicillin } 2 \mathrm{~g} \text { probenecid } 1 \mathrm{~g}\end{array}$ & $\begin{array}{l}\text { Failure } \\
\text { No follow-up }\end{array}$ \\
\hline $11(\mathrm{M}) \dagger$ & Nov & $\mathbf{U}$ & UK & Ampicillin $2 \mathrm{~g}$ probenecid $1 \mathrm{~g}$ & Cure \\
\hline $12(\mathrm{M}) \dagger$ & Nov & $\begin{array}{l}\mathrm{U} \\
\mathrm{U}\end{array}$ & UK & $\begin{array}{l}\text { Nil-patient recalled } \\
\text { Ciprofloxacin } 250 \mathrm{mg} \times 1\end{array}$ & No follow-up \\
\hline $13(\mathrm{M})$ & Dec & $\mathrm{U}$ & UK & Ampicillin $2 \mathrm{~g}$ probenecid $1 \mathrm{~g}$ & Cure \\
\hline 14(M) & Dec & $\mathbf{U}$ & UK & Ampicillin $2 \mathrm{~g}$ probenecid $1 \mathrm{~g}$ & Cure \\
\hline $15(\mathrm{M})$ & Dec & $\begin{array}{l}\mathrm{U} \\
\mathbf{U}\end{array}$ & $\begin{array}{l}\text { USA } \\
\ldots\end{array}$ & $\begin{array}{l}\text { Ampicillin } 2 \mathrm{~g} \text { probenecid } 1 \mathrm{~g} \\
\text { Ciprofloxacin } 250 \mathrm{mg} \times 1\end{array}$ & $\begin{array}{l}\text { Failure } \\
\text { Cure }\end{array}$ \\
\hline
\end{tabular}

$\mathrm{U}=$ urethra, $\mathrm{T}=$ throat, $\mathrm{C}=$ endocervix.

* Patients 1 and 2 were contacts; † patients 11 and 12 were contacts. 
Table III. Antimicrobial susceptibility of $N$. gonorrhoeae isolates with ciprofloxacin MIC $>0.008 \mathrm{mg} / \mathrm{L}$

\begin{tabular}{|c|c|c|c|c|c|c|c|c|c|}
\hline \multirow[b]{2}{*}{$\begin{array}{c}\text { Patient } \\
\text { no. }\end{array}$} & \multicolumn{6}{|c|}{$\mathrm{MIC}(\mathrm{mg} / \mathrm{L})$ of } & \multirow{2}{*}{$\begin{array}{c}\text { Zone size } \\
\text { (ciprofloxacin, } \\
0.1 \mu \mathrm{g} \text { disk) }\end{array}$} & \multirow{2}{*}{$\begin{array}{l}\text { Auxo- } \\
\text { type* }\end{array}$} & \multirow[b]{2}{*}{ Serovar } \\
\hline & $\begin{array}{l}\text { penic- } \\
\text { illin }\end{array}$ & tetracycline & $\begin{array}{l}\text { erythro- } \\
\text { mycin }\end{array}$ & $\begin{array}{l}\text { cefur- } \\
\text { oxime }\end{array}$ & $\begin{array}{l}\text { spectino- } \\
\text { mycin }\end{array}$ & $\begin{array}{c}\text { cipro- } \\
\text { floxacin }\end{array}$ & & & \\
\hline \multicolumn{10}{|c|}{ Acquired in the UK } \\
\hline 1 & 0.03 & 0.5 & $0 \cdot 12$ & 0.008 & 16 & 0.03 & 18 & proto & IB-6 \\
\hline \multirow[t]{2}{*}{2} & 0.03 & 1 & $0 \cdot 12$ & 0.008 & 16 & 0.03 & 19 & proto & IB-6 \\
\hline & 0.03 & 0.5 & $0 \cdot 12$ & 0.008 & 16 & 0.03 & 18 & proto & IB-6 \\
\hline \multirow[t]{3}{*}{4} & 0.06 & 0.5 & 0.5 & 0.03 & 16 & 0.06 & 12 & arg & IB-6 \\
\hline & 0.03 & 0.5 & 0.5 & 0.016 & 16 & 0.06 & 10 & arg & IB-6 \\
\hline & 0.03 & 0.5 & 0.5 & 0.016 & 16 & 0.06 & 18 & arg & IB-6 \\
\hline 5 & 0.03 & 0.25 & 0.5 & 0.016 & 16 & 0.03 & 16 & arg & IB-6 \\
\hline 6 & 0.03 & 2 & 0.06 & 0.008 & 16 & 0.03 & 23 & proto & IB-6 \\
\hline 7 & 0.06 & 1 & $0 \cdot 12$ & 0.016 & 16 & 0.03 & 20 & proto & IB-6 \\
\hline 8 & 0.03 & 1 & $0 \cdot 12$ & 0.008 & 16 & 0.03 & 20 & proto & IB-6 \\
\hline 9 & 0.03 & 1 & $0 \cdot 12$ & 0.008 & 16 & 0.03 & 14 & proto & IB-6 \\
\hline 11 & 0.06 & 0.5 & 0.5 & 0.016 & 16 & 0.03 & 18 & proto & NR \\
\hline \multirow{2}{*}{12} & $0 \cdot 06$ & $0 \cdot 25$ & 0.5 & 0.016 & 16 & 0.03 & 18 & proto & NR \\
\hline & 0.06 & 0.25 & 0.5 & 0.016 & 16 & 0.03 & 20 & proto & NR \\
\hline 13 & 0.06 & 0.5 & 0.5 & 0.06 & 16 & 0.06 & 13 & $\arg$ & IB-6 \\
\hline 14 & 0.03 & 0.5 & 0.5 & 0.016 & 16 & 0.06 & 13 & arg & IB-6 \\
\hline \multicolumn{10}{|c|}{ Acquired outside the UK } \\
\hline \multirow[t]{3}{*}{3} & 0.25 & 2 & 1 & 0.06 & 16 & 0.25 & $\ldots$ & proto & IB-26 \\
\hline & 0.5 & $>2$ & 1 & 0.12 & 16 & 0.25 & $\ldots$ & proto & IB-26 \\
\hline & 0.5 & 2 & 1 & 0.12 & 16 & 0.12 & $\cdots$ & proto & IB-26 \\
\hline \multirow[t]{2}{*}{10} & 0.25 & 2 & 1 & 0.06 & 16 & 0.06 & 16 & proto & IB-4 \\
\hline & 0.25 & 2 & 1 & 0.06 & 8 & 0.06 & 15 & proto & IB-4 \\
\hline \multirow[t]{2}{*}{15} & 32 & 2 & 1 & 0.12 & 16 & 0.12 & $\ldots$ & arg/pro & IB-7 \\
\hline & 32 & 2 & 1 & $0 \cdot 12$ & 16 & $0 \cdot 12$ & $\cdots$ & arg/pro & IB-7 \\
\hline
\end{tabular}

NR, non-reactive; proto, prototrophic; arg, arginine requiring; pro, proline requiring; . ., no zone.

acin, but the MICs of spectinomycin were similar for the two groups.

Further antimicrobial susceptibilities were measured for 102 strains, including all 23 with reduced ciprofloxacin sensitivity, the remaining 63 IB- 6 serovars, and a selection of 16 other serovars. Table IV shows the details of the results obtained with the ciprofloxacin-resistant isolates. Table V summarises results for the 79 ciprofloxacin-sensitive isolates. All 23 of the ciprofloxacin-resistant group were also resistant to nalidixic acid, ofloxacin and acrosoxacin. We have shown that seven of these isolates tested previously had reduced sensitivity to enoxacin and norfloxacin. ${ }^{5}$ Whereas MICs of the 4-quinolones for the foreign strains were similar to, or slightly higher than, those for isolates acquired in the UK, the difference was more marked for other antimicrobial agents, particularly cefoperazone and chloramphenicol. There was little difference in the susceptibility to fusidic acid or novobiocin in the two groups.

The most common treatment regimen for patients whose isolates were subsequently shown to have reduced sensitivity to ciprofloxacin was ampicillin (or amoxycillin) and probenecid (13 treatments). Five patients received ciprofloxacin. Patient 2 received ciprofloxacin after failing to respond to ampicillin and probenecid. Patient 4, who was hypersensitive to penicillin, failed to respond to oral co-trimoxazole and then to ciprofloxacin in a dose of $250 \mathrm{mg}$. Treatment with ciprofloxacin, $250 \mathrm{mg}$ twice a day for three days, resulted in cure. Patient 10 gave a history of contact in the Philippines and was treated on epidemiological grounds for a penicillinase-producing $N$. gonorrhoeae (PPNG) infection with ciprofloxacin $250 \mathrm{mg}$. Treatment failed and although the isolate had a penicillin MIC of $0.25 \mathrm{mg} / \mathrm{L}$, there was a successful response to ampicillin and probenecid. Patient 12 was hypersensitive to penicillin and received ciprofloxacin $250 \mathrm{mg}$. He did not attend for follow-up. Patient 15 acquired a PPNG in the USA and failed to respond to ampicillin and probenecid; ciprofloxacin, in a dose of $250 \mathrm{mg}$, subsequently cured the infection.

\section{Discussion}

Studies of the activity of the newer 4-quinolone compounds against $N$. gonorrhoeae have, for the most part, indicated a high level of activity; ${ }^{11}$ the few exceptions appear to have passed without comment, e.g. MICs of ciprofloxacin as high as $0.25 \mathrm{mg} / \mathrm{L}^{12,13}$ and even $8 \mathrm{mg} / \mathrm{L}^{14}$ Our review of the sensitivity of all clinical isolates of $N$. gonorrhoeae at St Thomas' Hospital indicates that strains with resistance to the 4-quinolones (e.g., ciprofloxacin MIC >0.008 mg/L) were not seen in intermittent studies before 1989 and were uncommon in 1989 when only $2.4 \%$ of isolates had an MIC of ciprofloxacin $>0.016 \mathrm{mg} / \mathrm{L}$. They formed two distinct groups, based on serogroup, place of acquisition and susceptibility to other antimicrobial agents. One group, those acquired in the UK, were, 
Table IV. Extended sensitivities for $N$. gonorrhoeae isolates with ciprofloxacin MIC $>0.008 \mathrm{mg} / \mathrm{L}$

\begin{tabular}{|c|c|c|c|c|c|c|c|c|c|c|}
\hline \multirow{2}{*}{$\begin{array}{c}\mathrm{Pa}- \\
\text { tient } \\
\text { no. }\end{array}$} & \multirow[b]{2}{*}{ Serovar } & \multicolumn{9}{|c|}{$\mathrm{MIC}(\mathrm{mg} / \mathrm{L})$ of } \\
\hline & & $\begin{array}{l}\text { nalidixic } \\
\text { acid }\end{array}$ & $\begin{array}{l}\text { ciproflox- } \\
\text { acin }\end{array}$ & $\begin{array}{l}\text { acrosox- } \\
\text { acin }\end{array}$ & ofloxacin & $\begin{array}{c}\text { cefo- } \\
\text { perazone }\end{array}$ & $\begin{array}{l}\text { chloram- } \\
\text { phenicol }\end{array}$ & rifampicin & fusidate & $\begin{array}{l}\text { novo- } \\
\text { biocin }\end{array}$ \\
\hline \multicolumn{11}{|c|}{ Acquired in the UK } \\
\hline 1 & IB-6 & 64 & 0.03 & 1 & $0 \cdot 12$ & 0.004 & 0.25 & 0.06 & 0.25 & 1 \\
\hline \multirow[t]{2}{*}{2} & IB-6 & 64 & 0.06 & 1 & 0.12 & 0.004 & 0.25 & 0.06 & 0.5 & 2 \\
\hline & IB-6 & 128 & 0.03 & 1 & 0.12 & 0.004 & 0.25 & 0.06 & 0.25 & 1 \\
\hline \multirow[t]{3}{*}{4} & IB-6 & 128 & $0 \cdot 12$ & 4 & 0.25 & 0.016 & 0.25 & 0.12 & 1 & 8 \\
\hline & IB-6 & 128 & $0 \cdot 12$ & 4 & 0.25 & 0.008 & 0.25 & 0.12 & 1 & 8 \\
\hline & IB-6 & 128 & $0 \cdot 12$ & 4 & 0.25 & 0.008 & 0.25 & 0.25 & 1 & 8 \\
\hline 5 & IB-6 & 128 & $0 \cdot 12$ & 4 & 0.25 & 0.016 & 0.25 & 0.25 & 1 & 8 \\
\hline 6 & IB-6 & 128 & 0.03 & 0.5 & $0 \cdot 12$ & 0.004 & $0 \cdot 12$ & $0 \cdot 016$ & $<0.12$ & 0.5 \\
\hline 7 & IB-6 & 128 & 0.06 & 1 & $0 \cdot 12$ & 0.004 & 0.25 & 0.12 & 0.5 & 1 \\
\hline 8 & IB-6 & 128 & 0.03 & 1 & 0.12 & 0.004 & 0.25 & 0.06 & 0.25 & 1 \\
\hline 9 & IB-6 & 64 & 0.06 & 1 & 0.12 & 0.004 & 0.25 & 0.03 & 0.25 & 1 \\
\hline 11 & NR & 16 & 0.06 & 1 & 0.25 & 0.016 & 0.25 & 0.12 & 0.5 & 2 \\
\hline \multirow[t]{2}{*}{12} & NR & 16 & 0.06 & 1 & 0.25 & 0.016 & 0.25 & $0 \cdot 12$ & 0.5 & 2 \\
\hline & NR & 16 & 0.06 & 1 & 0.25 & 0.016 & 0.25 & 0.12 & 0.5 & 2 \\
\hline 13 & IB-6 & 128 & 0.12 & 4 & 0.25 & 0.016 & 0.25 & 0.12 & 1 & 4 \\
\hline 14 & IB-6 & 128 & $0 \cdot 12$ & 4 & $0 \cdot 25$ & 0.008 & 0.25 & $0 \cdot 12$ & 1 & 4 \\
\hline \multicolumn{11}{|c|}{ Acquired outside the UK } \\
\hline \multirow[t]{3}{*}{3} & IB-26 & 128 & 0.25 & 4 & 0.5 & 0.03 & 2 & 0.25 & 1 & 2 \\
\hline & IB-26 & 128 & 0.25 & 4 & $0 \cdot 5$ & 0.03 & 2 & $0 \cdot 25$ & 0.5 & 2 \\
\hline & IB-26 & 128 & 0.25 & 4 & 0.5 & 0.03 & 2 & 0.25 & 0.5 & 2 \\
\hline \multirow[t]{2}{*}{10} & IB-4 & 128 & $0 \cdot 12$ & 4 & 0.25 & 0.03 & 2 & $>2$ & 4 & 4 \\
\hline & IB-4 & 128 & 0.12 & 4 & $0 \cdot 25$ & 0.03 & 2 & $>2$ & 4 & 4 \\
\hline \multirow[t]{2}{*}{15} & IB-7 & 256 & 0.25 & 4 & $0 \cdot 5$ & 0.03 & 2 & 0.25 & 1 & 4 \\
\hline & IB-7 & 256 & 0.25 & 4 & 0.5 & 0.03 & 2 & 0.25 & 1 & 4 \\
\hline
\end{tabular}

with the exception of three non-reacting isolates from two contacts, all IB-6 serovars and were generally sensitive to antimicrobial agents other than 4-quinolones. The other group consisted of strains acquired outside the UK; they were of different serovars and were multi-resistant.

There was no epidemiological evidence to link our UK patients except for two pairs who were contacts, so the predominance of the IB-6 serovars is of interest; $13(17 \%)$ out of a total of 78 IB-6 serovars were resistant to ciprofloxacin. Overall, IB-6 serovars accounted for $<10 \%$ of isolates at St Thomas' Hospital in $1989,<2 \%$ of 650 clinical isolates of non-

Table V. Antimicrobial susceptibility of $N$. gonorrhoeae isolates with ciprofloxacin MIC $<0.016 \mathrm{mg} / \mathrm{L}(\mathrm{n}=79)$

\begin{tabular}{|c|c|c|c|c|}
\hline $\begin{array}{c}\text { Antimicrobial } \\
\text { agent }\end{array}$ & $\begin{array}{c}\text { MIC range } \\
(\mathrm{mg} / \mathrm{L})\end{array}$ & $\begin{array}{c}\text { MIC } \\
\text { mean } \\
(\mathrm{mg} / \mathrm{L})\end{array}$ & $\begin{array}{l}\mathrm{MIC50} \\
(\mathrm{mg} / \mathrm{L})\end{array}$ & $\begin{array}{l}\mathrm{MIC} 90 \\
(\mathrm{mg} / \mathrm{L})\end{array}$ \\
\hline Penicillin & $0 \cdot 001-128$ & 0.0726 & $0 \cdot 12$ & $0 \cdot 25$ \\
\hline Tetracycline & $0 \cdot 12->2$ & 0.615 & 1 & 2 \\
\hline Erythromycin & $0.002-1$ & $0 \cdot 181$ & $0 \cdot 25$ & 0.5 \\
\hline Cefuroxime & $0.002-0.12$ & 0.0269 & 0.03 & 0.06 \\
\hline Cefoperazone & $<0.001-\quad 0.06$ & 0.00885 & 0.008 & 0.03 \\
\hline Ciprofloxacin & $0.001-\quad 0.008$ & 0.00206 & 0.002 & 0.004 \\
\hline Nalidixic acid & $1-2$ & $1 \cdot 25$ & 1 & 2 \\
\hline Ofloxacin & $0.004-0.03$ & 0.0129 & 0.016 & 0.016 \\
\hline Acrosoxacin & $0.004-0.06$ & 0.0338 & 0.03 & 0.06 \\
\hline Novobiocin & $0.12-8$ & 1.98 & 2 & 4 \\
\hline Spectinomycin & $4-32$ & $13 \cdot 7$ & 16 & 16 \\
\hline Fusidic acid & $0.06-4$ & 0.596 & 1 & 1 \\
\hline Chloramphenicol & $10.12-4$ & 0.420 & 0.25 & 2 \\
\hline Rifampicin & $0.03-2$ & $0 \cdot 138$ & $0 \cdot 12$ & 0.25 \\
\hline
\end{tabular}

penicillinase producing $N$. gonorrhoeae studied at St Mary's Hospital ${ }^{15}$ and $<3 \%$ of 1433 strains from a world-wide survey. ${ }^{8}$ Among the 4-quinolone-resistant IB-6 strains at St Thomas' Hospital, two auxotypes were found, suggesting that these isolates did not represent a single clone. A report from the PHLS Gonococcus Reference Unit suggested the spread of a single clone of gonococcus from Spain with a nonrequiring auxotype and non-groupable serovar. These isolates, and similar strains reported from Scotland, ${ }^{16}$ were penicillin-resistant and would appear not to correspond to our UK isolates. Nor do our findings accord with the suggestion from the Gonococcus Reference Unit that strains with reduced sensitivity to ciprofloxacin reflect an inevitable spread from South-East Asia, ${ }^{6}$ where quinolone resistance has been well documented. ${ }^{17}$

All our isolates were resistant to nalidixic acid and newer 4-quinolones, including both hydrophilic (ciprofloxacin, norfloxacin and ofloxacin) and hydrophobic (nalidixic acid and acrosoxacin) members of the group. However, strains that were acquired outside the UK also had reduced sensitivity to various unrelated antimicrobial agents - chloramphenicol, cefoperazone and tetracycline. In contrast, the UK isolates showed patterns of susceptibility to these agents typical of other sensitive gonococci. On the other hand, the non-groupable isolates from patients 11 and 12 had only marginally raised MICs of nalidixic acid. Therefore, we have evidence of three populations of 4-quinolone resistant gonococci. One consists of a heterogeneous group associated with multi-resistance 
and usually acquired abroad. ${ }^{6}$ The other two populations, acquired in the UK, include serovar IB-6 isolates that exhibit only 4-quinolone resistance and nongroupable isolates less resistant to nalidixic acid. The possible roles of altered DNA gyrase and reduced permeability to account for the resistance patterns remain to be investigated.

The reduction in ciprofloxacin susceptibility, although clinically significant, may be difficult to detect if a disk containing ciprofloxacin is used in routine sensitivity testing. We have since shown that on plate sensitivity testing, strains with an MIC of nalidixic acid of $>32 \mathrm{mg} / \mathrm{L}$ had no zone of inhibition around a disk containing $30 \mu \mathrm{g}$ of nalidixic acid, and strains with an MIC of ciprofloxacin of $\leq 0.008 \mathrm{mg} / \mathrm{L}$ all had a zone of inhibition of $\geq 31 \mathrm{~mm}$ diameter. We are now assessing the use of a 30- $\mu$ g disk of nalidixic acid to detect ciprofloxacin resistance in our routine clinical isolates.

Resistance to nalidixic acid has been noted before as an incidental finding in two of three acrosoxacinresistant isolates of $N$. gonorrhoeae. ${ }^{18}$ In that report, resistance to acrosoxacin appeared to develop during therapy with the compound.

The serovar of a strain of $N$. gonorrhoeae is determined by the epitopes exposed on the surface of the outer-membrane-protein $1 .^{8}$ Woodford et al. have suggested that the combination of epitopes may affect the conformation, and hence the permeability, of protein $\mathrm{I}$ which is a porin. ${ }^{15}$ Reduced membrane permeability is seen in $\mathrm{OmpF}$ porin-deficient mutants and accounts for 4-quinolone resistance in some Enterobacteriaceae. ${ }^{19-22}$ It is unlikely that this is the explanation for the predominance of the IB-6 serovar among our quinolone-resistant isolates, because the majority of our isolates of this serovar were sensitive strains.

At St Thomas' Hospital, ciprofloxacin has been used in the Department of Genito-urinary Medicine during the past 3 years, mainly for the treatment of uncomplicated PPNG infection or when PPNG was suspected before sensitivity results were available. Whether the appearance of 4-quinolone-resistant $N$. gonorrhoeae is related to increased use of the compounds in the community is unclear. Toour knowledge, our patients had not recently received ciprofloxacin.

We have now documented treatment failure with ciprofloxacin in a single oral dose of $250 \mathrm{mg}$ in two patients with "resistant" isolates, and one further treatment failure has occurred in 1990 . The possibility of failure should now be borne in mind, particularly when a 4-quinolone agent is used in low dosage for the treatment of a presumptive PPNG infection. The implications for the use of 4-quinolones in the eradication of pharyngeal carriage of meningococci remain to be assessed.

We thank the physicians of the Department of Genito-urinary Medicine at St Thomas' Hospital for permission to report their patients and Sarah Jerard for excellent technical assistance.

\section{References}

1. Oriel JD. Ciprofloxacin in the treatment of gonorrhoea and non-gonococcal urethritis. J Antimicrob Chemother 1986; 18: Suppl D 129-132.

2. Loo PS, Ridgway GL, Oriel JD. Single dose ciprofloxacin for treating gonococcal infections in men. Genitourin $\mathrm{Med}$ $1985 ; 61: 302-305$

3. Tegelberg-Stassen MJ, van der Hoek JC, Mooi L et al. Treatment of uncomplicated gonococcal urethritis in men with two dosages of ciprofloxacin. Eur J Clin Microbiol $1986 ; 5$ : 244-246.

4. Shahmanesh M, Shukla SR, Phillips I, Westwood A, Thin RW. Ciprofloxacin for treating urethral gonorrhoea in men. Genitourin Med 1986; 62: 86-87.

5. Gransden WR, Warren CA, Phillips I, Hodges M, Barlow D. Decreased susceptibility of Neisseria gonorrhoeae to ciprofloxacin. Lancet 1990; 335: 51 .

6. Jephcott A, Turner A. Ciprofloxacin resistance in gonococci. Lancet $1990 ; 335: 165$

7. Ison CA, Easmon CSF. Changes in penicillinase-producing Neisseria gonorrhoeae isolated in London. $J$ Med Microbiol 1989; 30: $239-244$.

8. Knapp JS, Tam MR, Nowinski RC, Holmes KK, Sanström EG. Serological classification of Neisseria gonorrhoeae with use of monoclonal antibodies to gonococcal outer membrane protein I. J Infect Dis 1984; 150 : 44-48.

9. Copley CG, Egglestone SI. Auxotyping of Neisseria gonorrhoeae isolated in the United Kingdom. J Med Microbiol 1983; 16: $295-302$.

10. Warren CA, Shannon KP, Phillips I. In-vitro antigonococcal activity of reosoxacin (WIN 35212). Br J Vener Dis 1981; 57: 33-35.

11. Phillips I, King A, Shannon K. In-vitro properties of the quinolones. In : Andriole VT (ed) The quinolones. London, Academic Press. 1988: 83-117.

12. Manek N, Andrews JM, Wise R. In-vitro activity of Ro 236240 , a new difluoroquinolone derivative, compared with that of other antimicrobial agents. Antimicrob Agents Chemother 1986; 30: 330-332.

13. Beskid G, Fallat V, Lipschitz ER et al. In-vitro activities of a dual-action antibacterial agent, Ro 23-9424, and comparative agents. Antimicrob Agents Chemother 1989; 33 : 10721077

14. Hardy DJ, Swanson RN, Hensey DM et al. Comparative antibacterial activities of temafloxacin hydrochloride (A62254) and two reference fluoroquinolones. Antimicrob Agents Chemother 1987; 31 : 1768-1774.

15. Woodford N, Bindayana KM, Easmon CSF, Ison CA. Associations between serotype and susceptibility to antibiotics of Neisseria gonorrhoeae. Genitourin Med 1989; 65 : 86-91.

16. Young H, Moyes A, Tait IB, McCartney AC, Gallacher G. Non-typable quinolone-resistant gonococci. Lancet 1990 ; 335: 604 .

17. Joyce MP, Aying BB, Vaughan GH et al. In-vitro sensitivity of Neisseria gonorrhoeae to quinolone antibiotics in the Republic of the Philippines. Sixth International Pathogenic Neisseria Conference, Atlanta, GA, 1988; Abstract E19.

18. MacAulay ME. Acrosoxacin resistance in Neisseriagonorrhoeae. Lancet $1982 ; 1$ : 171-172.

19. Hirai K, Aoyama H, Suzue S, Irikura T, Iyobe S, Mitsuhashi S Isolation and characterization of norfloxacin-resistant mutants of Escherichia coli K-12. Antimicrob Agents Chemother 1986; 30: 248-253.

20. Aoyama H, Sato K, Kato T, Hirai K, Mitsuhashi S. Norfloxacin resistance in a clinical isolate of Escherichia coli. Antimicrob Agents Chemother 1987; 31 : 1640-1641.

21. Hirai K, Aoyama H, Irikura T, Iyobe S, Mitsuhashi S. Differences in susceptibility to quinolones of outer membrane mutants of Salmonella typhimurium and Escherichia coli. Antimicrob Agents Chemother 1986; 29 : 535-538.

22. Hooper DC, Wolfson JS, Souza KS, Tung C, McHugh GL Swartz MN. Genetic and biochemical characterization of norfloxacin resistance in Escherichia coli. Antimicrob Agents Chemother 1986; 29: 639-644. 